\title{
7 Heavy metals in marine mammals
}

\author{
Krishna Das, Virginie Debacker, Stéphane Pillet \\ and Jean-Marie Bouquegneau
}

\section{Introduction}

During the past few decades, increasing concern about environmental pollution has led to many investigations on heavy metals and their distribution in the sea, air or biological materials. The distribution of xenobiotics in the marine environment is not homogeneous and a considerable variation of the concentrations may occur regionally and temporally. The use of bioindicators offers a useful alternative for pollution monitoring studies. Marine mammals appear to be potentially valuable indicators of the level of heavy metals accumulated in the marine environment: according to their top position in the trophic network, their long life span and their long biological half-time of elimination of pollutants, these animals accumulate high levels of chemicals such as organochlorines (Kamrin and Ringer, 1994; Tanabe et al., 1994), or heavy metals (Bouquegneau and Joiris, 1988, 1992; André et al., 1991a; Dietz et al., 1998). The increased interest in studying contaminants in marine mammals is due to large-scale die-off (Sarokin and Schulkin, 1992; Forcada et al., 1994) or impaired reproduction (De Guise et al., 1995), which could lead to population declines of some pinniped and small cetacean species in Europe and North America, and the finding of relatively large contaminant burdens in these animals. In many cases, morbillivirus infections were the primary cause of the disease outbreaks (Heide-Jørgensen et al., 1992; Thompson and Hall, 1993; de Swart et al., 1995a). These mass mortalities among seals and dolphins inhabiting contaminated marine areas have led to speculation about the possible involvement of immunosuppression associated with environmental pollution.

Controlled experiments are unavailable to establish any definite causal relation between these pollutant concentrations and any physiological problem. Moreover, the data are always difficult to interpret because of the presence of other chemical contaminants and other stressors. The physiological status of the organisms (e.g. pregnancy, moulting, fasting, etc.) also modulates the toxicity of heavy metals. In addition, the available measurements have almost been all performed on animals found dead, which leaves doubts about the general applicability of collected values at which an effect at individual or population level might be expected. 
Several investigations have been carried out in an attempt to evaluate contaminant effects at ambient environmental levels (Reijnders, 1986; Aguilar and Borrell, 1994; De Guise et al., 1995; de Swart et al., 1995b, 1996). For example, it has been demonstrated that seals fed polluted fish from the Dutch Wadden Sea showed reduced pup production when compared to those fed much less polluted fish from the Northeast Atlantic (Reijnders et al., 1986). This study was the first sign of a causal relationship between naturally occurring levels of pollutants and a physiological response in marine mammals.

A more recent study over a 2-year period by de Swart et al. (1994, 1995b, 1996) has demonstrated an impairment of several immune parameters in harbour seals (Phoca vitulina) fed herring from the polluted Baltic Sea when compared to those fed with fish from the Atlantic Ocean. Among impaired parameters, natural killer cell activity plays an important role in the first line of defence against viral infections (de Swart et al., 1996). Moreover, those seals consuming contaminated herring accumulated higher body burdens of potentially immunotoxic organochlorines than seals fed relatively uncontaminated herring. In the latter study, heavy metal levels have unfortunately not been determined either in fish or in seals.

Possible immunosuppressive actions of other groups of environmental contaminants, such as heavy metals, cannot be ruled out. Indeed, many laboratories and epidemiological studies have demonstrated the immunotoxic effects of heavy metals in a variety of species (Zelikoff and Thomas, 1998). Direct cause and effect links between a single kind of contaminant and possible population declines has not been established so far, and many researchers have proposed the possibility of a synergistic role of different substances in increasing the susceptibility of affected animals to diseases or biotoxins.

In this chapter we will focus on heavy metals and their possible effects on marine mammals. Heavy metals are usually divided into essential ( $\mathrm{Zn}$, $\mathrm{Cu}, \mathrm{Cr}, \mathrm{Se}, \mathrm{Ni}, \mathrm{Al})$ and non-essential metals $(\mathrm{Hg}, \mathrm{Cd}, \mathrm{Pb})$, the latter being potentially toxic even at low concentrations. Nickel and copper hazards to wildlife have been reviewed extensively by Eisler $(1997,1998)$. When considering marine mammals, there are limited data about heavy metals, except mercury. Chromium, nickel and lead concentrations are generally low, rarely exceeding a few $\mu \mathrm{g} / \mathrm{g}$ dry weight $(\mathrm{dw})$ in marine mammal tissues. No meaningful assessment of their toxicity in marine mammals can be made as yet (Law, 1996). However, investigations carried out on a ringed seal population (Pusa hispida saimensis) from Finland showed a clear connection between stillbirth of the pups and nickel concentrations in the air (Hÿvarinen and Sipilä, 1984). These authors have underlined the considerable nickel input in the environment from industrial activity in that particular area. On the other hand, zinc, copper, cadmium and mercury concentrations often exceed several tens of $\mu \mathrm{g} / \mathrm{g} \mathrm{dw}$ and so will be discussed in particular, as well as their levels in the different marine mammal groups, detoxification mechanisms, potential hazards and ecological implications. 


\section{Factors affecting heavy metal concentrations in marine mammals}

Some reviews about heavy metal contamination of marine mammals have been published (Wagemann and Muir, 1984; Thompson, 1990; Kemper et al., 1994; Law, 1994, 1996). Tables 7.1 to 7.5 present some selected references. It appears that metal concentrations vary greatly within marine mammals, especially those of non-essential metals such as cadmium and mercury (Table 7.1).

The large variation in these data (Table 7.1) illustrates the numerous physiological and ecological factors that might affect heavy metal contamination: geographic location, diet, age, sex, the tissues considered and metabolic rates. Information concerning metabolic rates is largely unavailable for the different marine mammals species so will not be discussed here. However it must be kept in mind that ingestion and assimilation rates differ between all the marine mammals species in relation with their weight and their migration or physiological status (fasting).

\section{Geographic location}

Heavy metal contamination sources can be both anthropogenic and natural, and distinguishing between the two can be very difficult. The natural

Table 7.1 Examples of maximum and minimum metal concentrations for marine mammals

\begin{tabular}{|c|c|c|}
\hline Metal & Minimum & Maximum \\
\hline \multirow[t]{5}{*}{$\mathrm{Hg}$} & 0.2 & 13156 \\
\hline & Muscle & Liver \\
\hline & Pusa hispida & Tursiops truncatus \\
\hline & Western Arctic & Mediterranean Sea \\
\hline & Wagemann et al. (1996) & Leonzio et al. (1992) \\
\hline \multirow[t]{5}{*}{$\mathrm{Cd}$} & 0.007 & 2324 \\
\hline & Muscle & Kidney \\
\hline & Pusa hispida (<1 year) & Pusa hispida (8 years) \\
\hline & Northwest Greenland & Northwest Greenland \\
\hline & Dietz et al. (1998) & Dietz et al. (1998) \\
\hline \multirow[t]{5}{*}{$\mathrm{Zn}$} & 2 & 4183 \\
\hline & Blubber & Liver \\
\hline & Leptonychotes weddellii (13 years) & Dugong dugon (>30 years) \\
\hline & Antarctic & Australia \\
\hline & Yamamoto et al. (1987) & Denton et al. (1980) \\
\hline \multirow{5}{*}{$\mathrm{Cu}$} & 0.4 & 600 \\
\hline & Blood & Liver \\
\hline & Leptonychotes weddellii (13 years) & Tursiops truncatus \\
\hline & Antarctic & Argentina \\
\hline & Yamamoto et al. (1987) & Marcovecchio et al. (1990) \\
\hline
\end{tabular}

When available, the age of the animals is given (all the data are expressed in $\mu \mathrm{g} / \mathrm{g}$ dry weight, assuming a mean water content of 75 per cent of the tissue). 


\section{K. Das et al.}

Table 7.2 Heavy metal mean and range concentrations in livers (and kidney for $\mathrm{Cd}$ ) from odontocetes: selected references

\begin{tabular}{|c|c|c|c|c|c|}
\hline Family & Species & Location & $\mathrm{n}$ (age estimation) & $H g$-total & $\mathrm{CH}_{3}-\mathrm{Hg}$ \\
\hline Pontoporiidae & $\begin{array}{l}\text { Pontoporia } \\
\text { blainvillei }\end{array}$ & Argentina & $\begin{array}{l}2 \\
(2 \text { and } 3 \text { years })\end{array}$ & $15 \pm 6$ & nd \\
\hline \multirow[t]{5}{*}{ Platanistidae } & \multirow[t]{2}{*}{$\begin{array}{l}\text { Platanista } \\
\text { gangetica }\end{array}$} & India & 4 & nd & nd \\
\hline & & Argentina & $\begin{array}{l}1 \\
\text { (10 years) }\end{array}$ & $344 \pm 29$ & nd \\
\hline & \multirow[t]{3}{*}{$\begin{array}{l}\text { Tursiops } \\
\text { truncatus }\end{array}$} & $\begin{array}{l}\text { South Carolina, } \\
\text { USA }\end{array}$ & 34 & $\begin{array}{l}71 \\
<2-586\end{array}$ & nd \\
\hline & & Gulf of Mexico & 10 & 180 & nd \\
\hline & & Alaska & 11 & $\begin{array}{l}180 \\
4-448\end{array}$ & nd \\
\hline \multirow[t]{8}{*}{ Delphinidae } & \multirow[t]{3}{*}{$\begin{array}{l}\text { Globicephala } \\
\text { melas }\end{array}$} & Faroë Islands & $\begin{array}{l}\mathrm{Hg}: n=8 \\
\mathrm{Cd}: n=28\end{array}$ & $852 \pm 776$ & $17 \pm 15 \%$ \\
\hline & & $\begin{array}{l}\text { Newfoundland, } \\
\text { Canada }\end{array}$ & 26 & $\begin{array}{l}63 \\
0.3-298\end{array}$ & nd \\
\hline & & Northeast & $\mathrm{Hg}: n=8$ & 206 & nd \\
\hline & \multirow{2}{*}{$\begin{array}{l}\text { Stenella } \\
\text { coeruleoalba }\end{array}$} & Atlantic & Others: $n=22$ & $5-348$ & \\
\hline & & $\begin{array}{l}\text { Pacific Ocean, } \\
\text { Japan }\end{array}$ & $\begin{array}{l}\text { Mature dolphins } \\
n=15\end{array}$ & $820 \pm 408$ & $3.4 \%$ \\
\hline & Delphinus & Northeast & 28 & 128 & $7 \%$ \\
\hline & delphis & Atlantic & Stranding & $3-631$ & \\
\hline & $\begin{array}{l}\text { Lagenorhynchus } \\
\text { albirostris }\end{array}$ & Newfoundland & 26 & $\begin{array}{l}3 \\
0.5-6\end{array}$ & nd \\
\hline \multirow[t]{7}{*}{ Monodontidae } & \multirow{2}{*}{$\begin{array}{l}\text { Monodon } \\
\text { monoceros }\end{array}$} & Baffin Island & 38 & $24 \pm 12$ & I \\
\hline & & $\begin{array}{l}\text { West } \\
\text { Greenland }\end{array}$ & $n>48$ & $\begin{array}{l}21^{\mathrm{a}} \\
<0.02-171\end{array}$ & l \\
\hline & \multirow{5}{*}{$\begin{array}{l}\text { Delphinapterus } \\
\text { leucas }\end{array}$} & West & 40 & 7 & I \\
\hline & & Greenland & & $0.3-123$ & \\
\hline & & $\begin{array}{l}\text { St. Lawrence, } \\
\text { Canada }\end{array}$ & 30 & $\begin{array}{l}134 \\
1.5-808\end{array}$ & l \\
\hline & & $\begin{array}{l}\text { Canadian } \\
\text { western Arctic }\end{array}$ & 77 & $\begin{array}{l}108 \\
1-464\end{array}$ & l \\
\hline & & $\begin{array}{l}\text { Canadian } \\
\text { eastern Arctic }\end{array}$ & 73 & $\begin{array}{l}41 \\
5-154\end{array}$ & I \\
\hline Kogiidae & $\begin{array}{l}\text { Kogia } \\
\text { breviceps }\end{array}$ & Argentina & 1 & 47 & l \\
\hline Physeteridae & $\begin{array}{l}\text { Physeter } \\
\text { macrocephalus }\end{array}$ & North Sea & 6 & $\begin{array}{l}41 \\
9-61\end{array}$ & $\begin{array}{l}5 \% \\
2-8 \%\end{array}$ \\
\hline \multirow[t]{4}{*}{ Phocoenidae } & \multirow[t]{3}{*}{$\begin{array}{l}\text { Phocoena } \\
\text { phocoena }\end{array}$} & North Sea & 5 & $\begin{array}{l}170 \\
1-504\end{array}$ & $37 \%$ \\
\hline & & Baltic sea & 4 & I & l \\
\hline & & $\begin{array}{l}\text { West } \\
\text { Greenland }\end{array}$ & 44 & $\begin{array}{l}16 \\
2-80\end{array}$ & I \\
\hline & $\begin{array}{l}\text { Phocoenoides } \\
\text { dalli }\end{array}$ & $\begin{array}{l}\text { Northwestern } \\
\text { Pacific }\end{array}$ & 3 & 6 & I \\
\hline
\end{tabular}

a Median.

When the range was not available, standard deviation was used. All the data are expressed in dry weight assuming a mean water content of 75 per cent of the tissues. 


\begin{tabular}{|c|c|c|c|c|c|}
\hline Cd liver & Cd kidney & $\mathrm{Se}$ & $\mathrm{Cu}$ & $Z n$ & Source \\
\hline $13 \pm 6$ & $40 \pm 16$ & nd & $64 \pm 9$ & $330 \pm 160$ & Marcovecchio et al. (1990) \\
\hline $\begin{array}{l}0.1 \\
<0.04-0.15\end{array}$ & $\begin{array}{l}2 \\
<0.04-6\end{array}$ & nd & $\begin{array}{l}207 \\
9-400\end{array}$ & $\begin{array}{l}126 \\
64-210\end{array}$ & Kannan et al. (1993) \\
\hline $3 \pm 1$ & $114 \pm 17$ & nd & $310 \pm 1$ & $785 \pm 136$ & Marcovecchio et al. (1990) \\
\hline 0.2 & nd & 38 & 43 & 227 & Beck et al. (1997) \\
\hline $0.02-1$ & & $0.7-189$ & $5-316$ & 46-1084 & \\
\hline $\begin{array}{l}2 \\
0.4-5\end{array}$ & nd & $\begin{array}{l}74 \\
41-133\end{array}$ & nd & nd & Kuehl and Haebler (1995) \\
\hline nd & nd & $\begin{array}{l}52 \\
6-114\end{array}$ & nd & nd & \\
\hline 308 & 344 & nd & nd & nd & Caurant et al. (1996) \\
\hline $6-668$ & $6-976$ & $0-480$ & $8-60$ & $100-900$ & Caurant and Amierd-Triquet (1995) \\
\hline 78 & 43 & 31 & 17 & 264 & Muir et al. (1988) \\
\hline $0-190$ & $0-102$ & $3-113$ & $9-35$ & $68-716$ & \\
\hline 17 & 91 & nd & 43 & 167 & Das et al. (2000) \\
\hline $0.2-51$ & $0.1-199$ & & $7-272$ & 33-385 & André et al. (1991b) \\
\hline nd & nd & $194 \pm 115$ & nd & nd & Itano et al. (1984) \\
\hline 6 & 13 & nd & 12 & 143 & Holsbeek et al. (1998) \\
\hline $0-96$ & $0.4-81$ & & $3-32$ & $65-293$ & \\
\hline 2 & 14 & 8 & 20 & 100 & Muir et al. (1988) \\
\hline $0.2-8$ & $2-44$ & $4-12$ & $3-32$ & $43-136$ & \\
\hline $133 \pm 130$ & $298 \pm 192$ & $16 \pm 7$ & $21 \pm 13$ & $151 \pm 40$ & Wagemann et al. (1983) \\
\hline $43^{\mathrm{a}}$ & $156^{\mathrm{a}}$ & & / & $144^{\mathrm{a}}$ & Hansen et al. (1990) \\
\hline$<0.06-295$ & $<0.06-500$ & $<0.8-144$ & & $53-271$ & \\
\hline 9 & 41 & & I & 114 & Hansen et al. (1990) \\
\hline$<0.06-34$ & & $2-111$ & & $87-181$ & \\
\hline 0.6 & 6 & I & I & $:$ & Wagemann et al. (1990) \\
\hline $0.004-2$ & $0.004-15$ & & & & \\
\hline 9 & 39 & 75 & 45 & 112 & Wagemann et al. (1996) \\
\hline $0.5-27$ & $15-88$ & $3-235$ & $3-140$ & $43-185$ & \\
\hline 26 & 90 & 21 & 77 & 115 & Wagemann et al. (1996) \\
\hline $0.03-103$ & $0.3-314$ & $1.5-91$ & $3-1324$ & $41-361$ & \\
\hline 30 & 1650 & / & 40 & 652 & Marcovecchio et al. (1990) \\
\hline 82 & 258 & 18 & 8 & 104 & Bouquegneau et al. (1997b) \\
\hline $52-175$ & $133-426$ & $6-43$ & $5-12$ & $90-125$ & Holsbeek et al. (1999) \\
\hline l & / & I & I & / & Joiris et al. (1991) \\
\hline 0.3 & 1.5 & l & 24 & 120 & Szefer et al. (1994) \\
\hline $0.3-0.4$ & $0.2-3$ & & $18-6$ & $96-144$ & \\
\hline 13 & 53 & 11 & 48 & 200 & Paludan-Müller et al. (1993) \\
\hline $0.2-45$ & $0.4-290$ & $2-36$ & $20-200$ & $145-370$ & \\
\hline / & I & I & I & I & Fujise et al. (1988) \\
\hline $0-84$ & $0-136$ & & $20-329$ & 110-186 & \\
\hline
\end{tabular}




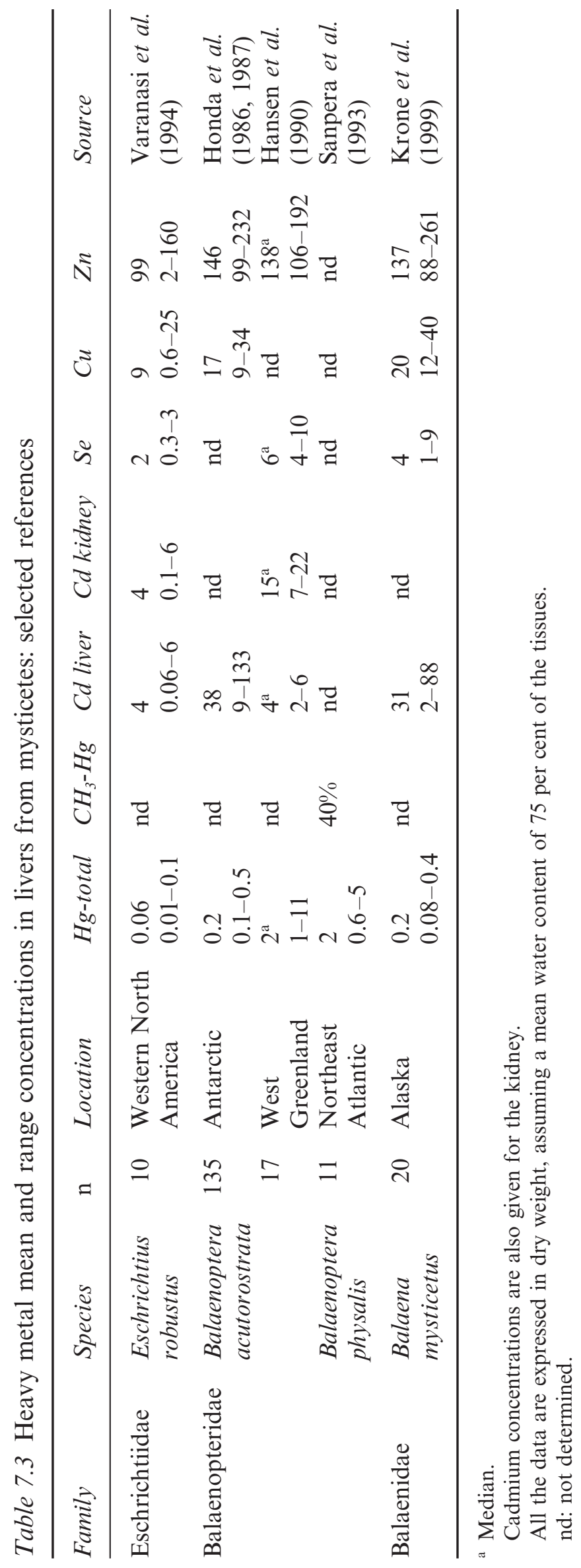




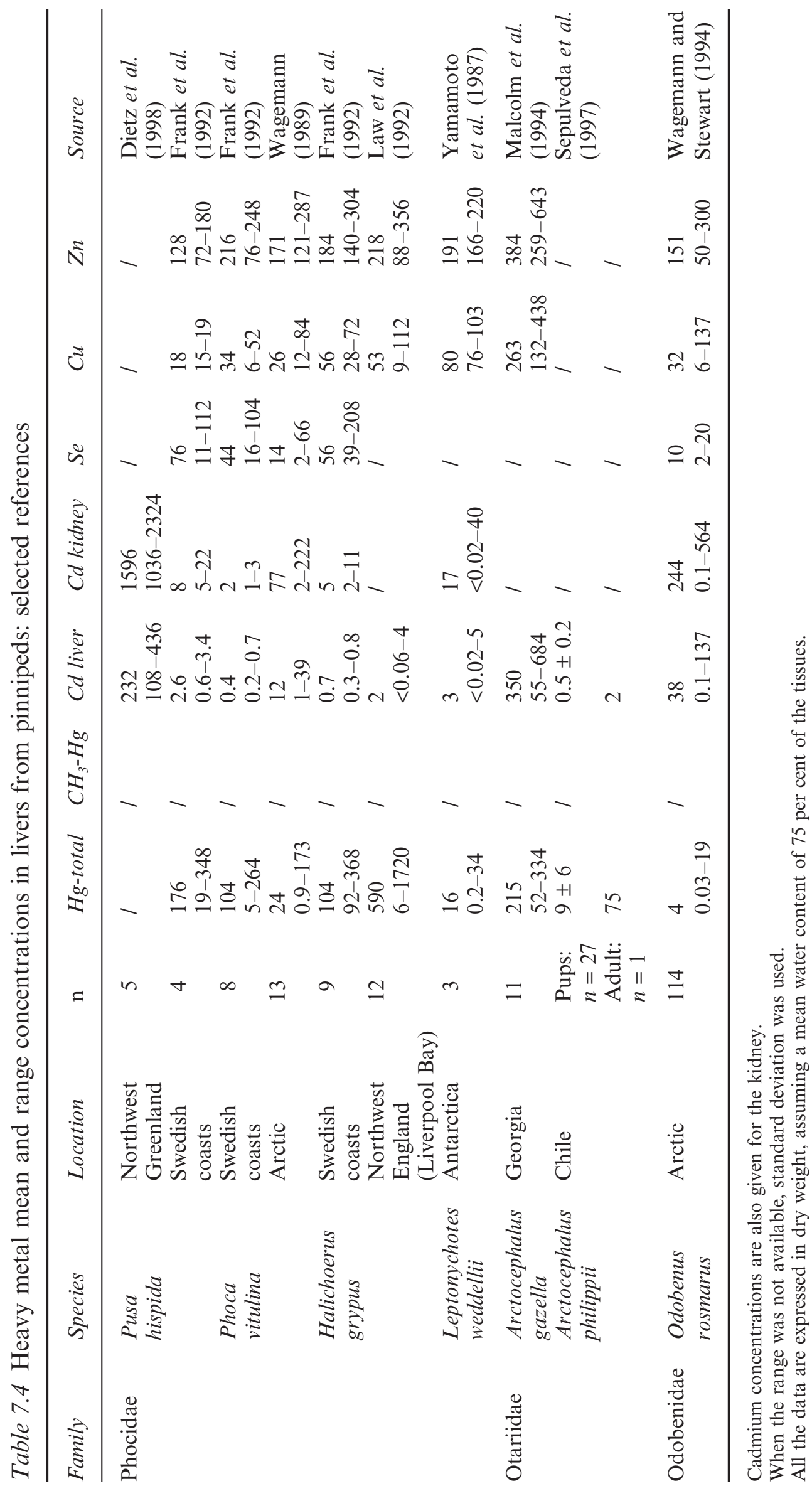


142 K. Das et al.

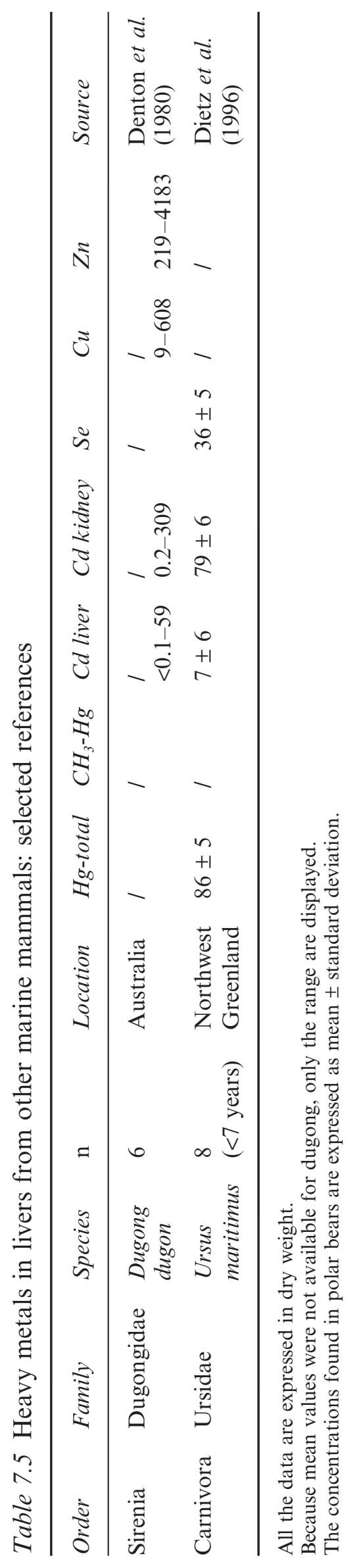




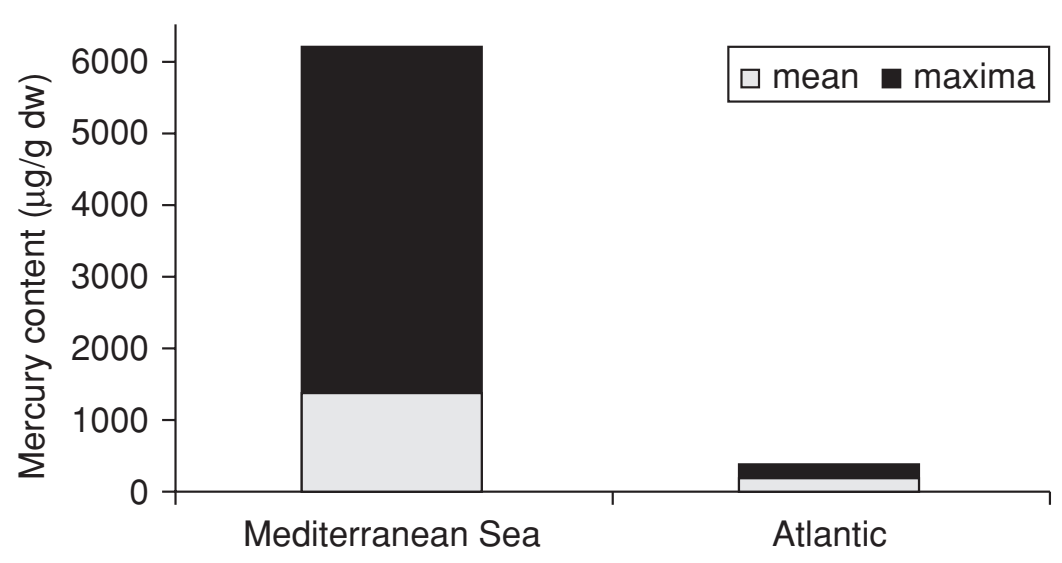

Figure 7.1 Mercury levels in livers from striped dolphins (Stenella coeruleoalba) from the north-east Atlantic and the Mediterranean Sea. Concentrations are expressed per gram dry weight, assuming a mean water content of 75 per cent of the tissues. (After André et al., 1991a, b.)

background component of the input of heavy metals in marine ecosystems may be as important as the anthropogenic one, and, in some areas, it appears to be the major source. This is important because it emphasises that marine mammals have been exposed to heavy metals long before the development of human activities. For example, this is the case for the Mediterranean Sea and the Arctic, which are known for their high natural metal levels: mercury in the Mediterranean Sea and cadmium in the Arctic.

The mercury levels measured in dolphins from the Mediterranean Sea are higher than those encountered in dolphins from Pacific coasts of Japan or the north-east Atlantic (Figure 7.1) (Honda et al., 1983; André et al., 1991a; Leonzio et al., 1992). According to André et al. (1991b), the origin of high mercury levels observed in Mediterranean dolphins is natural because of the large natural sources present in the Mediterranean basin.

The current state of knowledge of concentrations, spatial and temporal trends of contaminants, including heavy metals, have been described extensively in the Arctic (Muir et al., 1992; Dietz et al., 1996; AMAP, 1998). It seems that cadmium concentrations have always been high in the Greenland Arctic regions, as indicated by the lack of obvious temporal trends in sediment cores, as well as historic hair samples from the fifteenth century from both seals and Inuits (Dietz et al., 1998). Johansen et al. (1980) first reported that cadmium levels in tissues of ringed seals from Greenland were higher than previously reported for seals from the North Sea. Cadmium seems to accumulate to higher levels in seals living in unpolluted Arctic waters than in those taking their preys in the North Sea area, which receives large inputs of pollutants. A similar observation can be made for porpoises (Figure 7.2).

Wagemann et al. (1996) have investigated the heavy metal distribution in belugas (Delphinapterus leucas), narwhals (Monodon monoceros) and ringed seals within the Arctic region. Mean mercury concentrations in the livers of 


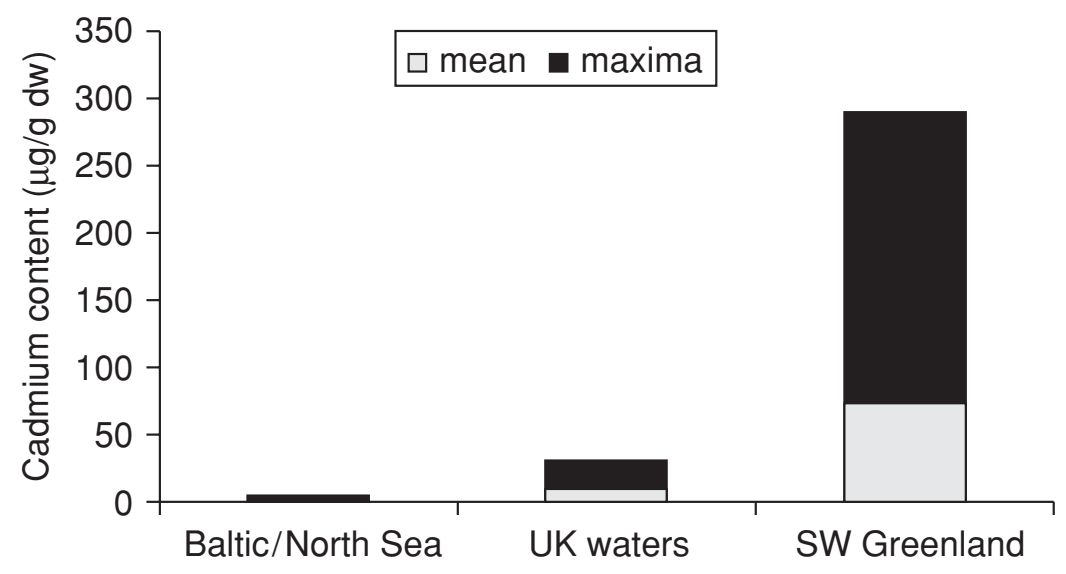

Figure 7.2 Cadmium levels in kidneys from porpoises (Phocoena phocoena) from the Baltic and North seas, and waters around the UK and south-western Greenland. Concentrations are expressed per gram dry weight, assuming a mean water content of 75 per cent of the tissues. (After Harms et al., 1978; Falconer et al., 1983; Paludan-Müller et al., 1993.)

belugas and ringed seals were significantly higher in the western Arctic than in the eastern Arctic. This comparison was not possible for narwhals, as they are not found in the western Canadian Arctic. On the contrary, cadmium as well as zinc and copper concentrations in tissues (liver and kidney) of belugas and ringed seals were higher in the eastern than in the western Arctic. These differences in metal levels between marine mammals of the eastern and western Arctic corresponded to the different geological settings and sediments of these two regions (Wagemann et al., 1995, 1996).

\section{Routes of entry}

There exist several different routes of entry of heavy metals in marine mammals: uptake from the atmosphere through the lungs, absorption through the skin, across the placenta before birth, via milk through lactating, ingestion of sea water and ingestion of food. Nevertheless, the major route of heavy metal contamination for marine mammals seems to be via feeding (André et al., 1990a, b; Augier, 1993b; Law, 1996). Considering this, the following discussion will mainly refer to the diet (including suckling) and its influence on metal uptake.

Obviously, mysticetes are less contaminated by heavy metals than odontocetes and pinnipeds (which are located at higher trophic levels in the marine food web). Cadmium seems to be transferred to the highest trophic levels of the marine food chain mainly by molluscs, particularly cephalopods, which concentrate cadmium in their viscera (Honda and Tatsukawa, 1983; Bouquegneau and Joiris, 1988; Miles and Hills, 1994). Long-finned pilot whales (Globicephala melas), for example, are known to concentrate cadmium in relation to a preferential cephalopod diet. Elevated levels of cadmium 
in Pacific walrus (Odobenus rosmarus divergens) and northern fur seals (Callorhinus ursinus) have been reported in a population of the Bering Sea, a remote area away from industrial activity (Miles and Hills, 1994). In an attempt to find out which prey may transfer cadmium to the walrus, the most common preys (mainly bivalves) found in the stomach contents were analysed for their metal concentrations. Amongst the bivalves analysed, Mya sp. showed the highest cadmium content, suggesting that this prey could be a cadmium transmitter for walruses (Miles and Hills, 1994). Wagemann and Stewart (1994) have studied heavy metal concentrations of walruses (Odobenus rosmarus rosmarus) from the eastern Canadian Arctic in relation to their food, mostly bivalves (Mya sp. and Serripes sp.). These authors showed that bivalves could also be a source of lead for walruses, judging from the correspondence between the high levels of lead in both bivalves and walruses (Wagemann and Stewart, 1994).

However, some high cadmium levels have been reported in some marine mammals that do not eat cadmium-contaminated prey (Denton et al., 1980). Trace metals have been determined in the dugong (Dugong dugon), which mostly feeds on seagrasses and algae. High cadmium and zinc concentrations have been detected in their livers and kidneys. Denton et al. (1980) have reported renal cadmium and hepatic zinc concentrations reaching, respectively, $309 \mu \mathrm{g} / \mathrm{g}$ and $4183 \mu \mathrm{g} / \mathrm{g}$ dry weight, while low levels of these metals are found in the seagrasses analysed. The authors suggested that the low levels of copper in seagrasses may influence intestinal absorption of zinc and cadmium in the dugong. Higher than normal zinc and cadmium absorption through the intestinal tract occurs when dietary copper intake is deficient, due to competition between the metals for available binding sites on carrier proteins within the intestine (Denton et al., 1980). Unlike dugongs of coastal Australia, which display a copper deficiency due to their seagrass diet, Florida manatees (Trichechus manatus) are considered to be facing the opposite problem: copper concentrations in the livers of Florida manatees were significantly elevated in areas of high herbicidal copper usage (O'Shea et al., 1984). Manatees might be inefficient at maintaining copper homeostasis in the face of dietary excess. The death of a captive dugong was attributed to exposure to copper sulphate added to its tank as an algicide (Oke, 1967).

The position of top predators in the food web influences mercury levels in marine mammals as this highly toxic metal is biomagnified, when available as methylmercury, through the food web (Bouquegneau and Joiris, 1988). Diets, and especially those of marine mammals relying on fish, are responsible for mercury contamination (Svensson et al., 1992; Nakagawa et al., 1997). Much higher mercury concentrations have been reported in minke whales (Balaenoptera acutorostra) from Greenland (Hansen et al., 1990) compared to Antarctic minke whales (Balaenoptera bonaerensis), which are several times less contaminated (Honda et al., 1986, 1987). Hansen et al. (1990) attributed the lower mercury concentrations found in tissues of Antarctic minke whales to differences in trophic levels and subsequently in the mercury content of 
the food items: northern minke whales feed mainly on fish while southern minke whales feed on krill. Indeed, the food web in the Antarctic ecosystem is rather simple, as the major food component is the Antarctic krill. The low trophic position of the Antarctic minke whale is reflected in the very low bioconcentration factor of mercury in this animal.

\section{Age}

Cadmium and mercury accumulated strongly with age in most marine mammal tissues analysed (e.g. Honda and Tatsukawa, 1981, 1983; Hamanaka et al., 1982; Honda et al., 1983; Augier et al., 1993b). This increase is enhanced in the liver in which the excretion rate might be extremely low due to the fossilisation of mercury under a detoxified form (see below). However, some exceptions have been reported in the literature. Honda et al. (1986, 1987) have studied the heavy metal distribution in Antarctic minke whales, and compared it to their food habit and age. The age of these whales varies between 1 and 45 years. They found maximum concentrations of cadmium and mercury in the livers of 20 -year-old minke whales. Both concentrations increase with age until about 20 years and thereafter decrease. Because there is no evidence that half-lives of cadmium and mercury change with age, Honda et al. $(1986,1987)$ suggested a higher food intake for the younger animals compared to older. They also suggested that these changes may be due to the significant decrease in stocks of blue whales (Balaenoptera musculus) and fin whales (Balaenoptera physalis). Both these species used to occupy ecological niches similar to those of the minke whales in the Antarctic marine ecosystems. The young minke whales would be less exposed to feeding competition from blue and fin whales, than the older ones. Accumulations of toxic metals such as cadmium or mercury may also have been influenced by this ecosystem disruption (Honda et al., 1986, 1987).

High copper and zinc concentrations have also been observed in very young animals and neonates (e.g. Julshamn et al., 1987; Wagemann et al., 1988; Caurant et al., 1994). These essential elements are known to increase in tissues undergoing rapid development and differentiation (Baer and Thomas, 1991). It has been suggested that these higher levels encountered in young might reflect a specific requirement in newborns or a very low excretion rate of these metals by the fetus (Wagemann et al., 1998).

\section{$\operatorname{Sex}$}

Reproductive activities such as pregnancy, parturition and lactation can modify the metal levels. Several studies have demonstrated that metal transfer from females to pups occurs through the placenta or lactation: Honda et al. (1987) reported a hepatic iron, cobalt, lead and nickel transfer from mother to pup. As a consequence, these metal concentrations decrease in the mature female with the progress of gestation. 
Canella and Kitchener (1992) found significantly lower levels of mercury in pregnant and lactating sperm whales (Physeter macrocephalus) when compared with non-breeding females. They suggested that this may be due to hormonal changes or stress causing the redistribution of mercury in body tissues.

\section{Distribution within organs}

The pattern of distribution of metals within the organism is tissue and metal specific. For example, mercury is mostly concentrated in the liver, with kidney and muscle having successively lower levels. On the contrary, the highest cadmium concentrations are usually encountered in the kidney, due to the presence of metal-binding proteins. This pattern prevails in most marine mammals (Wagemann and Muir, 1984).

Yamamoto et al. (1987) have studied the distribution of heavy metals in the whole organism of three Weddell seals (Leptonychotes weddellii) from the Antarctic. These authors estimated the whole metal body burden, which was calculated from the weight of the different tissues and their respective concentrations. If whole-body burdens of metal are estimated for an adult Weddell seal, zinc is mostly located in muscles and in bones, copper in muscles and liver, mercury in liver and muscles, and cadmium in liver and kidney. The apparent contrast between the low concentration of mercury generally measured in marine mammal muscles and the high burden encountered here is due to the high muscle mass of these animals. The redistribution of mercury from highly contaminated organs such as liver or kidney through muscles seem to be a protection mechanism against mercury toxicity (Cuvin-Aralar and Furness, 1991).

Skin contains generally low mercury concentrations (Yamamoto et al., 1987). However, the skin of marine mammals is not a homogeneous tissue. It consists of four distinct layers, in which mercury increases progressively outwards, with a concentration of $6 \mu \mathrm{g} / \mathrm{g}$ (estimation in dry weight) in the outermost layer of Arctic belugas and narwhals. During the process of moulting, the outermost and the underlying layers are shed, thus approximately 20 per cent of the total mercury in the skin is lost annually in belugas and 14 per cent in narwhals (Wagemann et al., 1996).

\section{Toxicity of mercury and cadmium}

As quoted above, the accumulation through the food chain is a major risk for top predators. The accumulation of chemical substances may result in toxic concentrations in organisms (secondary poisoning) even if the concentration in the environment remains below the threshold level for direct toxicity (Nendza et al., 1997). The finding of high concentrations of metals such as cadmium or mercury have raised the question about their toxicity. 
Reliable toxicity data for predating marine mammals are scarce. Instead, threshold levels are often extrapolated from terrestrial species, i.e. interspecies correlations are assumed to hold for rats or captive seals. The validity of these extrapolations is highly questionable and can only be justified by the current lack of better data and by ethical considerations. Indeed, potential effects of toxic metals cannot be tested in free-living animals because experimental manipulations are undesirable. In vitro experimentations or systematic post-mortem investigations to establish the disease status of contaminated animals in a relatively large number of individuals from the same species are complementary and valuable alternative ways of understanding the numerous processes involved.

\section{Mercury toxicity}

Mercury exists in several interchangeable forms in the biosphere (Kaiser and Tölg, 1980), but the mercury accumulation through the food web mainly occurs in an organic form, methylmercury $(\mathrm{MeHg})$, as a result of its lipid solubility and preferential assimilation during zooplankton grazing (Mason et al., 1995). Above zooplankton, organic mercury is biomagnified along the food chain up to marine mammals.

Total mercury concentration is a poor indicator of toxic effects, as organic mercury compounds seem to be considerably more toxic to animals than inorganic mercury. The biological and toxicological activity of mercury depends on the form that is taken up, the route of entry in the body (skin, inhalation or ingestion), and on the extent to which mercury is absorbed (Kaiser and Tölg, 1980). Wolfe et al. (1998) have recently reviewed the toxicity on mercury on wildlife.

In mammals, methylmercury toxicity is manifested primarily as central nervous system damage, including sensory and motor deficits and behavioural impairment. Animals become anorexic and lethargic. Methylmercury is easily transferred across the placenta (Wagemann et al., 1988) and thus concentrates in the fetal brain (Wolfe et al., 1998). This reproductive effect ranges from development alterations in the fetus to fetal death.

Methylmercury is also absorbed by the gastrointestinal tract, while inorganic salts of mercury are less readily absorbed. Mercury is absorbed from fish mainly as the methylated form since almost all the mercury present in fish is methylated (Svensson et al., 1992).

Experimental seal intoxication has led the animals to lethargy, weight loss and finally death (Ronald and Tessaro, 1977). Four harp seals (Pagophilus groenlandicus) were intoxicated with methylmercury by a daily oral intake. Two seals were fed with mercury doses of $0.25 \mathrm{mg} / \mathrm{kg}$ of body weight per day for 60 and 90 days. These two seals did not show abnormal blood concentrations but exhibited a reduction in appetite and consequent weight loss. Two others seals fed $25 \mathrm{mg} / \mathrm{kg}$ of body weight per day died on day 20 and day 26 of exposure. The measurements of blood parameters indicated toxic 
hepatitis, uraemia and renal failure. These pathologies have been related to high accumulation of mercury in these tissues. The liver concentrations reached more than $500 \mu \mathrm{g} / \mathrm{g}$ dry weight after the death. Almost 90 per cent of the mercury analysed in the liver was methylmercury. No detoxification mechanisms were described in this case.

However, this experimental study did not reproduce the real daily food intake of marine mammals in the wild. Nigro and Leonzio (1993) have calculated the mean daily food intake of small cetaceans to be approximately $3 \mathrm{~kg}$ of fish and cephalopods, with an average mercury concentration of $0.3 \mathrm{mg} / \mathrm{kg}$ fresh weight, from which the mean dietary mercury intake for an adult specimen can be estimated at $0.9 \mathrm{mg}$ mercury/day for the whole animal. This is quite far from the $25 \mathrm{mg} / \mathrm{kg}$ of body weight/day administrated in gel caps to seals in the study of Ronald and Tessaro (1977). Another feature that might explain the absence of detoxification is the absence of selenium added to the food. In the wild, if fish are a source of exposure to mercury, they are also a source of selenium (Svensson et al., 1992), and in marine mammals demethylation mechanisms occur in the presence of selenium (see below). In this experimental study, the lack of additional selenium in the diet was probably the limiting factor to detoxification.

Very few studies have tried to link metal concentrations measured in free-ranging marine mammals and health status (Hÿvarinen and Sipilä, 1984; Rawson et al., 1993, 1995; Siebert et al., 1999; Bennet et al., 2001). Only one case of mercury toxicity has been reported by Helminen et al. (1968): the ringed seal suspected of mercury intoxication was from an area of heavy industrial mercury dumping. Chronic mercury accumulation was associated with liver abnormalities observed in stranded bottlenose dolphins from the Atlantic. Large deposits of a brown pigment, identified as lipofuscin, in the portal areas of the liver were observed in the livers of nine animals with high hepatic mercury levels ( $>60 \mu \mathrm{g} / \mathrm{g}$ fresh weight). Analytical electron microscopy carried out on these pigments demonstrated that mercuric selenide (HgSe) was the predominant material (Rawson et al., 1995). Lipofuscin is believed to be derived from damaged subcellular membranes. This pigment accumulation strongly correlated with mercury concentrations. Mercury would have inhibited the activity of lysosomal digestive enzymes and, therefore, reduced degradation of proteins, leading to excessive accumulation of lipofuscin within cells and finally cell death (Rawson et al., 1993).

More recently, Siebert et al. (1999) examined the possible relationship between mercury tissue concentrations and disease in harbour porpoises from the German waters of the North and Baltic seas. A higher mercury content has been measured in organs of harbour porpoises from the North Sea compared to those of the Baltic Sea, indicating that mercury is a more important threat for animals of the North Sea than for those of the Baltic Sea. High mercury concentrations were associated with prevalence of parasitic infection and pneumonia. 
Bennet et al. (2001) have also used this indirect approach to investigate the prediction that increased exposure to toxic metals results in lowered resistance to infectious disease in harbour porpoises from the coasts of England and Wales. Mean liver concentrations of mercury, selenium, mercury : selenium ratio and zinc were significantly higher in the porpoises that died of infectious diseases (parasitic, bacterial, fungal and viral pathogens such as pneumonia), compared to porpoises that died from physical trauma (most frequently entrapment in fishing gear). Liver concentrations of lead, cadmium, copper, and chromium did not differ between the two groups.

In some cases, balances between elements seem to be more important than the absolute concentration when the possibility of toxic effects is considered. High premature birth rates have been observed and studied between 1968 and 1972 in the Californian sea lion (Zalophus californianus) from the southern California Channel Island rookeries (Martin et al., 1976). These premature pups were ataxic, had difficulties in breathing and died shortly after birth. Heavy metals were analysed and compared between normal and premature pups and between their respective mothers. The results revealed that severe imbalance in the mercury: selenium: bromine ratio occurred in the livers of the abnormal mothers. The absolute concentrations seemed not to be involved in this case as mercury, selenium and bromine were in higher concentrations in the livers of normal mothers compared to abnormal mothers. This suggests that the selenium : mercury balance is a very complex phenomenon and might be more important for general health status than absolute concentrations.

Some in vitro studies have also been carried out to evaluate the potential hazard of mercury in marine mammals. Freeman and Sangaland (1977) demonstrated that methylmercury alters the in vitro synthesis of steroid hormones which play an important role in reproduction. Genetic effects of methylmercury on lymphocytes of one bottlenose dolphin (Tursiops truncatus) have also been evaluated in vitro by Betti and Nigro (1996). Lymphocytes were isolated from blood obtained from a 15-year-old dolphin (Adriatic Sea). Methylmercury induces DNA single-strand breaks and cytotoxicity in a dose-dependent manner. The doses of $\mathrm{MeHg}$ used in this study are likely to be in the range of concentrations (between 1 and $10 \mu \mathrm{g} / \mathrm{ml}$ ) naturally occurring in the blood of wild dolphins found in the Mediterranean Sea (Betti and Nigro, 1996). It appears that dolphin lymphocytes have a greater resistance both to the genotoxic and cytotoxic effects of $\mathrm{MeHg}$ when compared to human or rat cells. This feature can be interpreted as an adaptation acquired by dolphins to counter the methylmercury exposure.

\section{Cadmium toxicity}

Cadmium is regarded as one of the most toxic metals. High dietary concentrations of cadmium in humans can lead to well-known heavy skeletal deformities ('itai-itai' disease), kidney lesions (mainly on the proximal 
tubules) usually preceding lung damage, dysfunction of cardiovascular and haematopoietic systems, as well as carcinogenic, mutagenic and teratogenic effects (Förstner, 1980; Lamphère et al., 1984; Jonnalagadda and Prasada Rao, 1993). The effect of cadmium on marine ecosystems has been reviewed recently (AMAP, 1998). The renal concentrations can reach levels as high as $2000 \mu \mathrm{g} / \mathrm{g}$ dry weight in some Arctic ringed seals (Dietz et al., 1998). This is much higher than the critical concentrations of approximately $800 \mu \mathrm{g} / \mathrm{g}$ dry weight $(200 \mu \mathrm{g} / \mathrm{g}$ fresh weight) associated with kidney damage in mammals including humans (WHO, 1992). Moreover, following Elinder and Järup (1996), this critical concentration has been largely overestimated, as cadmiuminduced renal dysfunctions have been displayed with kidney cortex concentrations of the order of $200 \mu \mathrm{g} / \mathrm{g}$ dry weight $(50 \mu \mathrm{g} / \mathrm{g}$ fresh weight). For comparison, in human adults, the renal cadmium concentrations amongst non-smokers is less than $5 \mu \mathrm{g} / \mathrm{g}$ fresh weight (Pesch et al., 1989). No obvious cadmium toxic effect has yet been registered in marine mammals, despite the high levels encountered in several species, suggesting highly efficient detoxification mechanisms (Dietz et al., 1998).

\section{Detoxification mechanisms}

The exposure of marine mammals to heavy metals has occurred throughout their evolutionary history, during which they have developed mechanisms either to control the internal concentration of certain elements or to mitigate their toxic effects. The most obvious case is that of mercury in dolphins.

Compared to other terminal consumers, such as tunas or seabirds, some marine mammals accumulate much higher levels of mercury, with biomagnification factors in respect to prey of 500 in dolphins compared to 30 in predatory fish, for example (Leonzio, 1996). This can be explained by physiological differences not only in the involved uptake and release, but also - and sometimes mainly - in detoxification processes.

\section{Mercury detoxification}

Wagemann and Muir (1984) found mercury and selenium concentrations reaching up to $510 \mu \mathrm{g} / \mathrm{g}$ fresh weight (approximately $2000 \mu \mathrm{g} / \mathrm{g}$ dry weight). Despite such extremely high values, the animals did not show any overt signs of mercury or selenium poisoning because the presence of the two elements together provided protection to the animal. Many studies have demonstrated the mutual antagonism between mercury and selenium (Pelletier, 1985; CuvinAralar and Furness, 1991). The mutual antagonism between these two elements has become one of the strongest and most general examples of interactions between heavy metals. This phenomenon occurs throughout the animal kingdom from oysters and shrimps to marine mammals and human beings. Koeman et al. $(1973,1975)$ first reported the strong correlation between mercury and selenium in livers of marine mammal species. A molar 


\section{$152 K$. Das et al.}

$\mathrm{Hg}$ : se ratio of approximately 1 has been observed, suggesting mercury detoxification mechanisms in the presence of selenium.

Different forms of mercury coexist in the environment. Methylmercury is known to be one of the most toxic. Mercury is transferred up to marine mammals in a methylated form. However, very small amounts of methylmercury are generally found in the livers of marine mammals: less than 10 per cent of mercury is present in a methylated form in the livers of adult marine mammals. Mercury also occurs in an inorganic form (Wagemann et al., 1998), which implies that a demethylation process occurs (Joiris et al., 1991). The fate of this inorganic mercury has been mainly elucidated by histological studies carried out in livers from specimens of Cuvier's beaked whale (Ziphius cavirostris) and bottlenose dolphins (Martoja and Viale, 1977; Martoja and Berry, 1980). These authors first observed granules composed of mercuric selenide (HgSe). Successively, similar granules were also described in the striped dolphin (Stenella coeruleoalba). Mercury and selenium occurred as dense intracellular granules, located mainly in the liver macrophages, the Kupffer cells, and in the proximal tubules of the kidney. These granules appear as spherical or polygonal particles ranging from 15 to $80 \AA$ (Augier et al., 1993a; Nigro and Leonzio, 1993, 1996).

More recently, Rawson et al. (1995) found HgSe crystals in both the liver and respiratory system of the bottlenose dolphin and short-finned pilot whale and reported $\mathrm{HgSe}$ in the lung and hilar lymph nodes associated with soot particles. In both the liver and hepatic lymph nodes, these crystals were small, averaging $50 \AA$. In the lung and hilar lymph nodes, the crystals were much larger, measuring 250-500 A. Abundant carbon was present in the hilar nodes, while only very small amounts were found in the hepatic nodes and in the liver. These findings suggest an alimentary and a respiratory entry for mercury in cetaceans: mercury in the liver is likely to be trophically acquired, passing through the gastrointestinal tract and carried to the liver by the way of portal veins. In the liver, it may be converted into $\mathrm{HgSe}$ which accumulates as an end product (Martoja and Berry, 1980). In animals producing large amount of $\mathrm{HgSe}$, some of this may be carried to the hepatic lymph nodes and even to the spleen (Rawson et al., 1995). HgSe in the lungs and the hilar nodes appears to be closely associated with carbon, suggesting an atmospheric association between these elements. Indeed, mercury and selenium pollution is largely attributed to the burning of fossil fuel or waste incinerations and these elements tend to aggregate as particles (Rawson et al., 1995). However, in vivo precipitation of $\mathrm{HgSe}$ into the surfaces of inhaled soot particles cannot be ruled out, and further investigations are needed to understand this lung accumulation process. These mercuric selenide granules seem to be the last step of a very efficient detoxification mechanism leading to high but non-toxic concentrations in the organs. The molar ratio of 1 has been generally observed in marine mammals. However, the $\mathrm{Hg}: \mathrm{Se}$ molar ratio found in the liver can vary within the range of 0.2 (Hansen et al., 1990) to 2.49 (Caurant et al., 1996). 
Palmisano et al. (1995) have explained this variation: a $\mathrm{Hg}$ : Se molar ratio of approximately 1 has been observed in the livers of striped dolphins only after a certain threshold in the total mercury concentration (approximately $100 \mu \mathrm{g} \mathrm{Hg} / \mathrm{g}$ fresh weight) has been exceeded. Palmisano et al. (1995) have proposed a two-stage mechanism for the demethylation and accumulation process. At low mercury levels (first stage) the metal is retained mainly in its methylated form. At higher mercury levels (second stage) demethylation, with a concurrent accumulation of selenium, seems to be the prevailing mechanism. Moreover, above the threshold only a small fraction of mercury is present in a labile form as $\mathrm{Hg}^{2+}$ and $\mathrm{MeHg}^{+}$bound to the cysteine residue. These authors have determined that 63 per cent of the total mercury analysed in the liver of one dolphin is involved in the formation of a very insoluble selenocompound, certainly present as $\mathrm{HgSe}$ (tiemannite), but in addition, mercury can be involved in the formation of other selenocompounds as Hg-selenoproteins. This hypothesis of a threshold has also been suggested in other studies dealing with mercury speciation (Sanpera et al., 1993; Caurant et al., 1996). Sanpera et al. (1993) have found no decrease in the organic mercury fraction with increasing total mercury concentration in the livers of fin whales (Balaenoptera physalis). On the contrary, Caurant et al. (1996) found a decreasing correlation between organic mercury and total mercury in the livers of long-finned pilot whales. Organic mercury was lower than 2 per cent when the total mercury concentration was higher than $100 \mu \mathrm{g} / \mathrm{g}$ fresh weight (400 $\mu \mathrm{g} / \mathrm{g}$ dry weight). Only a small fraction $(<1$ per cent) of total mercury is bound to heat-stable compounds (which include the metallothioneins). These heat-stable proteins are able to bind bivalent metals and are believed to participate in the heavy metal detoxification processes (see above). More than 90 per cent of the mercury was in the insoluble fraction, except in two animals. In these two individuals, insoluble mercury in the liver was less than 90 per cent and 14 and 35 per cent of the mercury was bound to metallothioneins. These individuals exhibited total mercury concentrations below $50 \mu \mathrm{g} / \mathrm{g}$ fresh weight (200 $\mu \mathrm{g} / \mathrm{g}$ dry weight) in their livers. When total mercury was higher than this value, the percentage bound to metallothioneins was low, always less than 1 per cent, whatever the total mercury concentration (Caurant et al., 1996).

In some species, mercury concentrations can be low during their entire life span. Fin whales feed at the bottom of the trophic web (Sanpera et al., 1993) and their mercury levels stay relatively low. In their livers, the mean ratio of organic/total mercury is about 40 per cent. This result seems very high compared to other data (see Table 7.6). The authors suggest that demethylation is carried out at a constant rate, probably because concentrations remain low throughout their life span, between 50 and $500 \mu \mathrm{g} / \mathrm{g}$ dry weight (Sanpera et al., 1993). It seems in this case that the specific threshold has not been reached and so high percentages of organic mercury are observed in the livers. 
K. Das et al.

Table 7.6 Comparison of mean percentage (\%) methylmercury to total mercury in suckling marine mammals compared to adults

\begin{tabular}{llll}
\hline Species & Pups & Adults & Sources \\
\hline Pagophilus groenlandicus & 70 & 14 & Wagemann et al. (1988) \\
Stenella coeruleoalba & 45 & 2.5 & Itano et al. (1984) \\
Globicephala melas & 55 & 17 & Caurant et al. (1996) \\
\hline
\end{tabular}

Young marine mammals can display a high percentage of methylmercury (Table 7.6), suggesting that they do not reach a specific threshold (Palmisano et al., 1995). A second hypothesis is that young individuals are still unable to demethylate mercury efficiently (Caurant et al., 1996).

\section{Cadmium detoxification}

As quoted above, the concentrations of cadmium in kidneys of marine mammals can reach levels more than two times the critical concentrations of approximately $800 \mu \mathrm{g} / \mathrm{g}$ dry weight ( $200 \mu \mathrm{g} / \mathrm{g}$ fresh weight) associated with kidney damage in terrestrial mammals, including humans (WHO, 1992). This raises questions about the health status of such heavily cadmiumcontaminated marine mammals. Dietz et al. (1998) have compared kidneys with low and high cadmium contamination from ringed seals from northwest Greenland, by macroscopic and light microscopic examination. No differences in renal morphology could be observed between experimental groups. These investigations indicate that marine mammals appear to be able to maintain considerable concentrations of cadmium without showing renal damage. Dietz et al. (1998) have therefore postulated that ringed seals are adapted to the naturally high cadmium levels of the Greenland Arctic regions.

\section{Role of metallothioneins}

Marine mammals might mitigate the toxic effects of cadmium through its binding to metallothioneins (reviewed by Das et al., 2000). The role of metallothioneins in cadmium detoxification has often been raised since the first isolation of this protein in horse kidney cortex by Margoshes and Vallee (1957). The presence of these low molecular weight proteins has been further demonstrated in many organisms, ranging from blue-green algae to primates (Kägi, 1991). These soluble and heat-stable proteins are found in the cytosolic fraction of the tissues. They are quite unique as they are characterised by a high cysteine content, divalent ion inducibility, such as $\mathrm{Cu}^{2+}$ and $\mathrm{Zn}^{2+}$, and high affinity in the binding of these cations (Kägi, 1991; Roesijadi, 1992, 1996). The primary function of metallothioneins is the homeostasis of essential heavy metals, specifically zinc and copper. Zinc-thionein levels 